\title{
Exploring web language orientation in emerging markets: The case of Serbia and the Ukraine
}

Received (in revised form): 7th April, 2008

\begin{abstract}
William L. James
is Professor of Marketing and International Business at Hofstra University. He earned his PhD in Marketing from the Krannert School of Management at Purdue University. His research has appeared in many marketing and management journals.
\end{abstract}

\section{Gladys Torres-Baumgarten}

is Associate Professor of Management and International Business at Kean University. She received her PhD in International Business from Rutgers University.

\section{Goran Petković}

is Professor in the Economic faculty at the University of Belgrade teaching courses in retailing, marketing and commerce. He earned his PhD from the University of Belgrade. Currently he is also serving as state secretary for tourism in the Serbian Economic Ministry.

\section{Tetyana Havrylenko}

is Assistant Professor of Marketing at National Technical University of Ukraine 'Kiev Polytechnic Institute', Kiev, Ukraine.

Keywords online marketing communication, internet usage, emerging markets (or Eastern Europe), language preference

\begin{abstract}
This paper looks at the issue of language selection in international online communications. Traditionally, online communications have primarily been written in English, and justified by the fact that English is the 'language of commerce'. This assumption ignores the issue that local language use in international online communications could lead to better firm performance in international markets. While English may be appropriate in some circumstances, the effectiveness of online marketing communications may also be compromised. This issue is particularly relevant today as the number of non-English web users has surpassed the number of English-speaking web users, and as web penetration in developing markets continues to expand. While online user preference for English vis-àvis a native language may vary by country, this paper argues that language selection for online communications must be given more serious consideration by multinationals in developing effective communication strategies, and that English should not automatically be considered the language of choice. The issue of language preference was investigated via an empirical study of web user preferences in two emerging markets: Serbia and the Ukraine. Seven psychographic scales were selected from the literature on the basis of their likelihood in differentiating between types of internet usage. The results suggest that country-by-country orientations are likely to vary - even within a region - and that these differences must be considered by international firms in devising effective internet communications.

Journal of Targeting, Measurement and Analysis for Marketing (2008) 16, 189-202. doi:10.1057/jt.2008.10
\end{abstract}

Correspondence: Gladys Torres-Baumgarten, Kean University,

1000 Morris Ave., Management Department,

Willis Hall 403, Union, NJ 07083, USA.

Tel: + 9087374167 ;

Fax: +908 7374165 ;

E-mail: gbaumgar@kean.edu

\section{INTRODUCTION}

Many global firms have embraced internet communications as integral parts of their international communication strategies. Until 
recently, however, firms largely assumed that online communications in English would be suitable for international markets since English is the 'universal language of business'. While this assumption may be more convincing for portions of the $\mathrm{B} 2 \mathrm{~B}$ segment, it ignores the linguistic preferences within the $\mathrm{B} 2 \mathrm{C}$ segment, (as well as others in the $\mathrm{B} 2 \mathrm{~B}$ sector). The dynamic profile of worldwide internet users, the internet's increased penetration into emerging markets and recent service introductions targeted at non-English speaking cyber users (such as chat services in local dialects ${ }^{1}$ ) bring into question whether the automatic use of English in web communications is the most appropriate online linguistic choice. These changes have prompted the managing director of Yahoo! India to predict that 'the next big growth [in India] will come from local language users'. Predictions like this and recent new service introductions suggest that it is necessary to understand how web users' language sensitivities affect usage of online services. International marketers need to pay closer attention to linguistic diversity and how it may affect web usage when developing online communications for international markets.

Accommodating these differences remains a major challenge as firms seek to identify the most effective web strategy in international markets. Although many companies use the internet in their arsenal of marketing weapons, there are always doubts about how to approach consumers in international markets. This issue is exacerbated when international markets are also emerging markets. This paper addresses the paucity of internet research in emerging market regions by focusing on two countries in Central and Eastern Europe: Serbia and the Ukraine. The markets' uncertainty as they transition out of the command economies that dominated the region throughout much of the 20th century makes it a particularly complex business environment.

Language selection in a region such as Central and Eastern Europe can be even more challenging as some groups remain loyal to their eastern roots, while others align themselves more closely with Western ideals.
The objective of this paper is to look at how language preferences can influence web usage and that of other communication devices. A clearer understanding of consumers' linguistic predilections for online communications in international markets will enable marketers and other international businesses to develop more effective web strategies and online communications. In turn, firms with a digital presence and appropriate web strategies in emerging markets may contribute to the continued and accelerated adoption of the internet.

Research on online users in highly developed internet markets, such as North America, Western Europe, and even China, has garnered significantly more attention than have small- and mediumsized emerging markets and their online populations. The focus of this paper is Serbia and the Ukraine, where internet diffusion (in comparison to other more mature internet markets) is in its early stages. Serbia and the Ukraine evolved from two very different historical models: the latter, a former state of the USSR; and Serbia, a part of the Socialist Federal Republic of Yugoslavia, an Eastern European nation that maintained its independence and its neutrality. The infrastructure in each country differs, with Serbia's infrastructure heavily affected by the government's support of Serbs involved in the civil wars in Bosnia and Herzegovina, Croatia and Slovenia. The resulting Nato embargo and military campaign ruined the infrastructure and economy of Serbia. The Ukraine's infrastructure is still divorcing itself from the effects of Soviet dominance. An earlier study of Central Europe ${ }^{2}$ suggests that there are few differences in internet behaviours within Eastern Europe. The present authors, however, questioned the assumed homogeneity within the region, particularly as the two markets of interest represent two historically different country models. If differences in internet preferences arise within the region, then this may call into question firms' practices of developing regionally oriented (as well as global) websites, and may serve as a call to greater localisation of websites. A review of the extant literature on firms' internet strategies and web usage behaviour 
follows, as well as a section identifying the dynamic nature of online users today.

\section{LITERATURE REVIEW}

\section{Internet global perspectives: Developed and developing markets}

The internet continues its global expansion with penetration rates in 2007 of nearly 70 per cent in North America, 54 per cent in Australia and nearly 40 per cent in Europe. ${ }^{3}$ While diffusion of the internet in North America is far greater than in other world regions, the actual number of internet users in North America $(233,188,086$ as of $3 / 2007$ ) now pales in comparison to the online population in Europe $(319,092,225$ as of $6 / 2007)$ and Asia $(409,421,115$ as of 6/2007). In fact, North American users now account for only 20 per cent of worldwide internet users. ${ }^{3}$ At the same time, the online population in emerging market regions continues to grow at a faster pace than in developed market regions. From 2000 to 2007, the online population in emerging market regions (Latin America, Middle East and Africa) increased by 466 per cent, 491 per cent and 640 per cent, respectively. This compares to 114 per cent growth in North America, 204 per cent in Europe and 146 per cent in Australia over the same time-frame. ${ }^{3}$ Despite the impressive growth over the past seven years, internet penetration in emerging market regions remains low. The internet penetration rate in Latin America, for example, is now slightly over 18 per cent, 11 per cent in Asia and 10 per cent in the Middle East ${ }^{3}$ suggesting that the needs of the online population from emerging markets must be better understood if internet penetration in those markets is to come within reach of the penetration levels seen in developed markets.

Multinational firms with an online presence initially viewed the internet as an effective vehicle for reaching global consumers. International web presence was often accomplished efficiently with the use of standardised websites in multiple markets. English was often the preferred language, while the online strategies and text largely appealed to Western consumers. ${ }^{4}$ Internet users, however, outside North America now clearly outnumber internet users within North America. ${ }^{3}$ The dynamic profile of the online population suggests that multinational firms may need to reevaluate their internet strategies, particularly with regard to the internet's use in developing market regions such as Asia, Latin America and Eastern Europe vis-à-vis the developed market regions of North America, Western Europe and Australia. Academic researchers, however, have given scant attention to internet usage behaviour in emerging market regions, with one recent exception. ${ }^{5}$ DiGregorio et al. confirmed the existence of a digital divide between developed and emerging markets and suggested that the divide may be bridged if public and private sector investments in emerging markets are made in the following areas: computer and internet infrastructure development, reduction in the cost of telecommunications and in enhancing English-language capabilities, to name a few. English language capabilities were found to affect e-business activities and, while this is not surprising in light of the preponderance of English-language websites up until now, it ignores the needs of individuals from countries with few English language speakers, and those whose internet capabilities are developing using local rather than international languages.

Recent data show that the online population is certainly evolving. The preferred language for online users continues to be English (Table 1), but Chinese is the second most popular language among internet users (albeit a distant second, 36 per cent and 13 per cent, respectively). The diversity of languages shown in the table also underscores the need for firms with an internet presence to reassess their international web strategies. Of particular concern to firms with online consumers worldwide is the discrepancy between the common languages used worldwide, and those used on the internet. The five most commonly used languages on the internet are also languages that are spoken by a large percentage of the worldwide population. (ie the top five internet languages are also among the top ten languages worldwide.) But as firms direct their internet strategies outside of these major language areas, they encounter a multitude of local 
Table 1: Internet languages

\begin{tabular}{|c|c|c|c|}
\hline $\begin{array}{l}\text { Top ten } \\
\text { languages in } \\
\text { the internet }\end{array}$ & $\begin{array}{l}\text { Internet users } \\
\text { by language }\end{array}$ & $\begin{array}{l}\text { Users as } \\
\% \text { of total } \\
\text { internet }\end{array}$ & $\begin{array}{l}\text { Language } \\
\text { rank by } \\
\text { internet } \\
\text { usage }\end{array}$ \\
\hline English & $326,781,864$ & 28.9 & 1 \\
\hline Chinese & $166,001,513$ & 14.7 & 2 \\
\hline Spanish & $100,966,903$ & 8.9 & 3 \\
\hline Japanese & $86,300,000$ & 7.6 & 4 \\
\hline German & $58,711,687$ & 5.2 & 5 \\
\hline French & $56,368,344$ & 5.0 & 6 \\
\hline Portuguese & $40,216,760$ & 3.6 & 7 \\
\hline Korean & $34,120,000$ & 3.0 & 8 \\
\hline Italian & $30,763,940$ & 2.7 & 9 \\
\hline Arabic & $28,540,700$ & 2.5 & 10 \\
\hline $\begin{array}{l}\text { Top ten } \\
\text { languages }\end{array}$ & $894,795,150$ & 82.3 & \\
\hline $\begin{array}{l}\text { Rest of the } \\
\text { Languages }\end{array}$ & $200,155,783$ & 17.7 & \\
\hline World total & $1,128,927,494$ & 100.0 & \\
\hline Serbia & $1,400,000$ & & $\begin{array}{c}13.9 \% \\
\text { penetration } \\
\text { rate }\end{array}$ \\
\hline \multirow[t]{2}{*}{ Ukraine } & $5,278,100$ & & $11.5 \%$ \\
\hline & & & $\begin{array}{c}\text { penetration } \\
\text { rate }\end{array}$ \\
\hline
\end{tabular}

Source: http://www.internetworldstats.com for language data (last updated on 6/2007) http://www.internetworldstats.com for Serbia and Ukraine (last updated on 3/2007)

languages, mastery of which is necessary if consumers are to be effectively reached.

While the importance of language in business communications has long been recognised, there is evidence that suggests that despite this belief, exporters in their $\mathrm{B} 2 \mathrm{~B}$ transactions still use English primarily. ${ }^{6}$ Clarke looked at the use of foreign languages by Irish exporters and found that there was a discrepancy between the perception that language capabilities are important in business success and the extent to which discussions or transactions were actually done in foreign languages. He found that nearly 90 per cent of Irish exporters felt that English was likely to become the business language of choice in the European Union and that only 10 per cent of the Irish exporters felt their business was negatively affected by a lack of language skills. While this research was done in the $\mathrm{B} 2 \mathrm{~B}$ context, it may lead some to question whether this may also hold in the $\mathrm{B} 2 \mathrm{C}$ sector - and whether this would be applicable in the web context, suggesting that a standardised approach may be an effective online communications strategy. Other authors have looked at a similar case; ${ }^{7}$ that of Scottish exporters' need for foreign language capabilities in the normal course of business. Their study of all marketing communications, including web communications, found that the more proactive companies were in fact using multilingual - or localised - approaches in their internet communications.

\section{Globalising or localising internet communications}

Decisions regarding standardised versus localised web content is reminiscent of the 50-year old marketing debate centering on standardisation versus localisation of a firm's marketing activities. ${ }^{8}$ Proponents of standardised web communications would argue that it offers cost efficiencies and the additional marketing benefit of one, unified message seen worldwide. On the other hand, those favouring localised messages would argue that the needs of international online users are best served by tailoring communications to their individual needs, and possibly, using the local language.

While firms may opt to use a localised approach in their web communications, portal firms may also decide to use greater localisation. It is only recently that researchers have begun to measure preference for local ethnic portals (versus global internet sites). ${ }^{9-12}$ Some researchers looked at how large US-based internet firms (eg Yahoo, AOL, etc) established country-specific websites in Europe, Asia and Latin America and found that there were many circumstances prompting global firms to develop locally-oriented websites. ${ }^{12}$ (Yahoo, for example, currently offers e-mail services in $35+$ different languages ${ }^{1}$ and is expanding its service offerings into new languages.) Others found that Japanese firms are inclined to develop localised websites to meet the needs of their international customers. ${ }^{9}$ In China, researchers found that ethnic portals successfully attracted nonEnglish speaking web users to the internet. ${ }^{10}$ In developing market studies, Asia has dominated academic research because of its sheer size and growth potential.

In seeking global efficiency, many firms have implemented standardised strategies in their internet communications, opting for standardised 
content, format and, at times, even language (with English being the most commonly used language for website development). The global approach has been used by international firms in their communications with consumers, as well as by portal firms with an international presence. ${ }^{11}$ This practice was largely implemented by US portal firms, although Robles also indicates that some portal firms have adopted regional approaches to their internet communications, tailoring the language and content of their web communications to the particular needs of a region, for example German-based T1 online, Spain's Terra-Lycos and Latin America's StarMedia. Still other portal firms used primarily local approaches in their web strategy. Local portal firms are also now competing with global portal firms, and their competitive edge is often based on offering similar services, but in local languages.

The three strategies outlined call into question how firms may best optimise their web communications. Clearly the most effective internet strategies must take account of consumers' internet behaviours. We argue that prior to the development of effective strategies for internet communications, the consumer behaviour of web users must be better understood. This is particularly pertinent since internet consumer behaviour in emerging nations is likely to differ from those of developed, industrialised nations, particularly with regard to language preferences and internet behaviours. Both issues are addressed in our study for Serbia and the Ukraine, but before describing the study in detail a discussion on the dynamic nature of the online population follows.

\section{Consumer behaviour and the internet}

Earlier internet research had focused on internet users in the US ${ }^{13,14}$ and Western Europe. Donthu and Garcia ${ }^{13}$ identified differences between online shoppers and nonshoppers. Blake et al. ${ }^{14}$ also looked at internet shopping behaviour by US users. Since the study focused on shopping behaviour, it was conducted in the US where online shopping is an accepted practice, given the popularity of credit card transactions and the focus on online credit card security. Internet buying behaviour in other markets, and in particular, emerging markets, however, is likely to differ from consumers' online shopping behaviour since the infrastructure for online purchases is not as developed as in the US. This further suggests that the one-size-fits-all approach to internet marketing initiatives may not be the most effective tactic for all markets.

Finally, there have been few cross-cultural studies of internet usage. Lynch and Beck's study ${ }^{2}$ was one of the first of this nature in which respondents were from a broad spectrum of cultures and countries (20 in total). The authors found evidence that suggested that the 'global' consumer continues to be an elusive concept and that internet users worldwide exhibit key differences that influence their internet usage behaviour. The authors recommended that firms with a digital presence should develop regional eb strategies since differences in web behaviour existed primarily between regions (and to a lesser extent within regions). The regiocentric approach offers cost efficiencies within regions, but also is locally responsive and would allow firms to tailor make their web presence to the needs of individual regions.

\section{Eastern European internet behaviours}

Former states of the USSR have varied considerably in the extent to which they have embraced technology. For instance, 2003 data estimate that 17.2 per cent of the population in Latvia owns a personal computer; 10.9 per cent of Lithuanians own a personal computer, while only 1.8 per cent of Ukrainians own one. ${ }^{15}$ The latest data from the World Factbook ${ }^{16}$ demonstrate this variability with estimated internet usage in Eastern Europe ranging from about 3 per cent in Bosnia and Herzegovina to an estimated 37 per cent in Slovenia and 41 per cent in Latvia. The latest internet statistics on Europe ${ }^{3}$ indicate that internet penetration rates in Serbia and the Ukraine as of March 2007 are 13.9 per cent and 11.5 per cent, respectively. 
Lynch and Beck ${ }^{2}$ were among the first researchers to include Eastern European internet users in their study since respondents were sought from Poland and the Czech Republic. The authors found few differences between Polish and Czech internet users' web surfing behaviour. The position of these countries is relevant as they are Central European - at the crossroads between Western and Eastern Europe, and that attitudinally their proximity to Western Europe effectively differentiates them from the other transitional economies of Eastern Europe (such as Serbia and the Ukraine). Poland's and the Czech Republic's 'western' orientation is supported by their recent acceptance into the European Union in May 2004.

While Lynch and Beck's study is an important work on cross-cultural influences on internet usage behaviour, it has several limitations. One drawback is their use of a sample in which all respondents were drawn from the professional ranks in the consulting firm in which they worked. Such convenience samples limit generalisations to broader sample frames of internet users as professionals have incomes and education levels higher than those of the general public. Secondly, the findings may be contaminated by corporate culture effects since all respondents worked for the same professional services firm and their behaviour may be atypical of the population overall. Thirdly, the authors found that no statistical differences occurred among their Eastern European respondents, findings at odds with other regions where within region differences were found. Finally, respondents were given a simulated shopping task to perform, and thus only e-commerce/transaction behaviour was analysed, and not the full spectrum of e-marketing activities.

The present study contributes to the growing literature on ethnic portals and internet usage behaviour by examining website preferences in two Eastern (rather than Central) European nations. Much of the research carried out on Eastern Europe has tended to ignore country-bycountry nuances. ${ }^{17}$ In particular we look at country-specific factors (eg communications infrastructure) and personal factors (eg online consumer behaviour). Serbia and the Ukraine were selected for this study because they are examples of markets in the earlier stages of internet adoption. Understanding internet usage behaviour in low penetration markets should help identify strategies for faster diffusion of the internet. It is known that both markets have experienced significant growth over the past decade, but are still in the early stages of internet adoption. ${ }^{18}$ In both instances, the governments sought to limit diffusion of the internet or its content during earlier points in its brief history, and internet content in the local language is limited.

The Ukraine has experienced slow growth in its telecommunications infrastructure; its annual growth in phone lines is slower than in other lower middle-income countries. Internet usage is concentrated in the large cities, and in 1999, one out of every 100 city residents had access to the internet (while the country average was approximately one out of every 500 residents). Serbia's telecommunications infrastructure, on the other hand, was virtually destroyed after Nato bombings in $1999 .^{18}$

In sum, the two countries of interest in our study - Serbia and the Ukraine - may be more representative of emerging markets within Eastern Europe with regards to their telecommunications infrastructure and to internet adoption and usage, and as a result may help us understand obstacles to internet adoption and diffusion in Eastern Europe and possibly other emerging markets.

\section{Measuring internet behaviours: Scales and variables}

In order to identify differences in internet usage, seven psychographic scales were selected from the marketing and internet literature. The mediating role that each scale plays in affecting web behaviour will be evaluated in the Serbian and Ukrainian context. The scales in this study include: attitude towards advertising, attitude towards computers, consumer ethnocentrism, consumer innovativeness (both cognitive and sensory), opinion leadership and web shopping risk attitudes.

Attitude towards advertising ${ }^{19}$ was selected as a measure of the respondents' orientation toward 
Western-style economies. Similarly, attitude towards computers ${ }^{20}$ was also included as a measure of respondents' technological orientation. The more positive the attitude towards technology and the more accepting of Westernstyle economies that consumers are, the more likely they might visit websites that are not in their local language.

Consumer ethnocentrism, a subscale of the national identity scale (or NATID) was also utilised $^{21}$ to determine whether strong nationalism was associated with web users' preference for ethnic portals. Consumer innovativeness has two subscales: cognitive innovativeness and sensory innovativeness. ${ }^{22}$ While cognitive innovativeness could be associated with the use of either English or ethnic portal websites, sensory innovativeness was deemed to be linked to an inclination to try new things, and therefore a willingness to adopt the internet, and also a greater preference for English websites (rather than ethnic portals).

Opinion leadership will also be measured utilising the latter of the two refinements. ${ }^{23,24}$ This scale was selected because the more likely that respondents were perceived as opinion leaders, the more likely that they would be associated with internet usage. The web shopping risk attitude scale ${ }^{20}$ will also be utilised to analyse web consumer behaviour in the two countries of interest.

As firms' global reach expands in tandem with increases in internet usage, firms with a digital presence are faced with the difficult decision of standardising or localising their web strategies, language and content. This study aims to provide some guidance in this effort, albeit for two specific countries (Serbia and the Ukraine) within one particular emerging market region (Eastern Europe).

\section{HYPOTHESES}

\section{Innovativeness:}

The internet is used by a relatively small proportion of the population in both countries of interest and thus can be viewed as being early in its lifecycle. The product lifecycle literature in marketing identifies the first group of adopters as innovators. Innovators are typically characterised as young, well educated and venturesome. ${ }^{25}$ Goldsmith $^{26}$ found that innovativeness predicts both frequency of online buying and intentions to purchase online. Venkatraman and Price ${ }^{22}$ identified two dimensions of innovativeness: cognitive and sensory. Those high in sensory innovativeness are likely to seek novel sensory experiences. Novel sensory experiences are more likely to be found when visiting websites that are different in language and content from local websites. Those high in cognitive innovativeness may find stimulation by web browsing in any language that they speak. Thus:
$\mathbf{H}_{1 \mathbf{a}}$ : Sensory innovativeness will be positively related to external orientation in web browsing.

\section{$\mathbf{H}_{\mathbf{1 b}}$ : Cognitive innovativeness will be unrelated or negatively related to external orientation in web browsing.}

\section{Opinion leadership:}

Opinion leaders are the influencers who make or break an innovation. They represent the norm of their group and thus are not normally among the first to try an innovation. Some research has looked at opinion leaders who are also innovators. ${ }^{27,28}$ The results have been generally weak except in the fashion industry. In general, however, opinion leaders are viewed as early adopters who wait to see the experiences of innovators before trying and endorsing a new product. Since the internet is still in its infancy in the countries under study, it is likely that opinion leaders still are primarily browsing in their local language. Thus:

$\mathbf{H}_{2}$ : Opinion leadership will be negatively related to external orientation in web browsing.

\section{Consumer ethnocentrism:}

Consumers that are ethnocentric are most likely to browse national websites in their native 
language and have little interest in anything perceived as foreign. Thus:

$\mathbf{H}_{3}$ : Consumer ethnocentrism will be negatively related to external orientation in web browsing.

\section{Attitude toward computers:}

The aspect of technology most closely associated with the internet is the computer. Researchers have found that one of the predictors of internet usage is a positive attitude towards technology. ${ }^{15}$ Technologies closely linked to the internet include ownership of a PDA, ownership of a cellular telephone and ownership of a computer. The number of internet technologies used and attitude towards computers should also be positively related to attitudes towards technology. Thus:

$\mathbf{H}_{\mathbf{4} \mathbf{a}}$ : Attitude towards computers will be positively related to external orientation in web browsing.

$\mathbf{H}_{\mathbf{4 b}}$ : Ownership of a PDA will be positively related to external orientation in web browsing.

$\mathbf{H}_{\mathbf{4}}$ : Ownership of a cellular telephone will be positively related to external orientation in web browsing.

$\mathbf{H}_{4 \mathrm{~d}}$ : Ownership of a personal computer will be positively related to external orientation in web browsing.

$\mathbf{H}_{4 \mathrm{e}}$ : The number of internet technologies used will be positively related to external orientation in web browsing.

\section{Attitudes toward risk:}

In general consumers are risk averse so the greater the perceived risk, the less likely the behaviour. The more something is perceived as different or foreign, the more one might expect avoidance. Thus:

$\mathbf{H}_{5}$ : High web risk attitude will be negatively related to external orientation in web browsing.

\section{Attitudes toward advertising:}

Advertising is more likely to be associated with Western-style economies. Thus, Serbians may have had more experiences than Ukrainians. A positive attitude might suggest a willingness to explore beyond one's own environment. Thus:

$\mathbf{H}_{6}$ : Attitude toward advertising will be positively related to external orientation in web browsing, especially for Serbians.

\section{Demographics:}

Demographic variables such as age, education and gender are all related to internet usage. ${ }^{15}$ Indeed the GVU internet surveys ${ }^{29}$ reflect the impact of these variables in the early years of the internet.

Users tended to be male, in their 20s and college educated. In addition heavier users are likely to explore more and hence have an external orientation.

$\mathbf{H}_{7 \mathbf{a}}$ : Males are more likely to engage in external orientation in web browsing.

$\mathbf{H}_{7 \mathbf{b}}$ : Younger users are more likely to engage in external orientation in web browsing.

$\mathbf{H}_{\mathbf{7 c}}$ : Those who have attended or completed college are more likely to engage in external orientation in web browsing.

$\mathbf{H}_{7 \mathbf{d}}$ : Hours spent on the internet will be positively related to external orientation in web browsing.

\section{METHODOLOGY}

\section{Sampling:}

Samples were gathered in Serbia and the Ukraine. Since internet usage in the Ukraine in 2000 was estimated at 1 per cent of the population ${ }^{30}$ and more recently at 11.5 per cent ${ }^{31}$ and was largely concentrated in the largest urban areas, sampling was restricted to Kiev. A similar situation was faced in Serbia with less than 2 per cent of the population estimated to be internet users in $2000,{ }^{32}$ while more recent estimates put the number at about 13.9 per cent. ${ }^{33}$ Since they are 
also largely concentrated in urban areas, sampling was restricted to Belgrade. Restricting the samples to the major urban area in each country was thus a pragmatic decision, but it means that countrywide generalisations could be misleading if internet users outside of those urban areas exhibit internet usage behaviour that differs significantly from the present samples.

In the Ukraine sample, collection took place in computer clubs (where you can play computer games, work with documents and print them) and INternet cafés. Two survey gatherers were assigned to each of the city's ten districts and independently surveyed ten people at two different locations. Every third person was surveyed with the exception that if the percentage of women participating fell below 40 per cent, the data collector would wait until the next possible participant was female. A total of 400 surveys were collected, with only five people refusing to participate. The resulting Ukrainian sample consisted of 233 (58 per cent) internet users, 208 males (52 per cent), 252 computer owners (63 per cent), 184 cellular phone owners (46 per cent), and nine PDA owners (2 per cent). The largest age group consisted of those between 20 and 29 years $(130=33$ per cent $)$; and the largest education group were university graduates or above $(163=41$ per cent). On average, they spent $11.9 \mathrm{~h}$ a week on the internet and used 3.6 of the internet technologies.

Eight data collectors interviewed Serbians in Belgrade: (seven achieved 50 complete interviews, while one was only able to complete 48 interviews). Interviews were conducted at many locations including: internet cafés, university computer labs, computer game places and retail stores/company workplaces. The resulting Serbian sample consisted of 345 internet users (87 per cent), 208 males (52 per cent), 288 computer owners (72 per cent), 362 cellular phone owners (91 per cent) and 13 PDA owners (3 per cent). The largest age group consisted of those between 20 and 29 years $(208=52$ per cent), and the largest education group consisted of those with some university experience $(193=49$ per cent $)$. On average, they spent $12.7 \mathrm{~h}$ a week on the internet and used 3.2 of the internet technologies.

\section{Psychographic scales:}

Seven psychographic scales were selected from the marketing and internet literature. They were selected on the basis of their likelihood in differentiating between types of internet usage. These scales measured: attitude towards advertising, attitude towards computers, consumer ethnocentrism, consumer innovativeness (both cognitive and sensory), opinion leadership and web shopping risk attitudes.

Attitude towards advertising was measured using a five-point Likert scale on three items as previously used. ${ }^{19}$ Attitude towards computers was measured using a five-point Likert scale on four items as previously used. ${ }^{20}$ Consumer ethnocentrism, a subscale of NATID, was measured using a five-point Likert scale on five items. ${ }^{21}$ Consumer innovativeness has two subscales (cognitive innovativeness and sensory innovativeness), each consisting of eight questions measured on five-point balanced labelled scales (strongly dislike, dislike, neutral, like, strongly like). ${ }^{20}$ Opinion leadership consisted of five items measured on five-point scales with only the end points labelled. ${ }^{23}$ This scale modified the original opinion leadership scale developed by King and Summers. ${ }^{24}$ The web shopping risk attitude scale $^{20}$ consists of three items measured on a fivepoint Likert scale.

To measure the reliability of these scales Cronbach's coefficient alpha was calculated. Table 2 presents these reliability measures. It is recommended that in the early stages of research on constructs, reliabilities of approximately 0.7 will suffice, while for basic research reliabilities of approximately 0.8 are sufficient. ${ }^{34}$ Two of our scales (ethnocentrism and opinion leadership) have coefficient alphas greater than 0.8 , four scales have coefficient alphas of approximately 0.7 and one scale, attitude towards advertising, has a coefficient alpha of about 0.5 . The reliability of this latter scale is clearly unacceptably low and was thus dropped from subsequent analyses. The four scales with coefficient alphas of about 0.7 have received considerably less construct testing and refinement than consumer ethnocentrism or opinion leadership. Thus, these four scales, especially in an international environment, might 
Table 2: Cronbach's coefficient alpha for psychographic scales

\begin{tabular}{ll}
\hline Attitude towards advertising & 0.5339 \\
Attitude towards computers & 0.7507 \\
Consumer ethnocentrism & 0.8332 \\
Cognitive innovativeness & 0.7401 \\
Sensory innovativeness & 0.6954 \\
Opinion leadership & 0.8432 \\
Web shopping risk attitude & 0.7183 \\
\hline
\end{tabular}

reasonably be considered to still be in their early stages of construct refinement where coefficient alphas of 0.7 are acceptable.

\section{Demographic and usage variables:}

Information collected on internet usage included: average number of hours spent on the internet in a week; the percentage of websites visited that were in various languages (eight choices plus other); and usage of nine Internet tools - e-mail, text messaging, instant messaging, online banking, online stock trading, streaming video, streaming audio, online purchase with payment on delivery and online purchase with payment via bank card (each coded as $0=$ never used; $1=$ used).

Demographic variables included: gender $(0=$ female; $1=$ male); age (under 20; 20-29; 30-39; 40-49; 50+); highest level of education (elementary; secondary; trade or vocational; some university; university graduate or above); ownership of a PC $(0=$ do not own; $1=$ own $)$; ownership of a PDA $(0=$ do not own; $1=$ own $)$; and ownership of a cellular phone $(0=$ do not own; 1 = own).

\section{RESULTS}

The analytical approach used was binary logistic regression. The binary dependent variable split respondent self-reported web browsing behaviour based on the percentage of the websites visited that were in the local language.

Table 3 shows the languages used in web browsing by our two samples. The Serbian sample primarily utilises English and Serbian language websites, while the Ukrainian sample primarily uses Russian and Ukrainian language websites. The dependent variable was designed as a rough proxy for a relatively external versus relatively local orientation in internet usage. The objective was to identify the top and bottom thirds of each
Table 3: Language of websites visited

\begin{tabular}{lrrr}
\hline $\begin{array}{l}\text { Language of } \\
\text { websites visited }\end{array}$ & $\begin{array}{l}\text { Serbian } \\
\text { sample }\end{array}$ & $\begin{array}{l}\text { Ukrainian } \\
\text { sample }\end{array}$ & Overall \\
\hline English & 64.66 & 16.71 & 44.93 \\
French & 0.95 & 0.14 & 0.62 \\
German & 1.55 & 1.12 & 1.37 \\
Italian & 0.44 & 0.13 & 0.31 \\
Russian & 0.57 & 56.10 & 23.42 \\
Serbian & 29.64 & 0.37 & 17.60 \\
Spanish & 0.67 & 0.01 & 0.40 \\
Ukrainian & 0.08 & 25.24 & 10.45 \\
Other & 0.59 & 0.21 & 0.44 \\
\hline
\end{tabular}

sample (ie the two tails of the distribution). In the Serbian sample, this resulted in 127 respondents who reported that at least 40 per cent of the websites visited were in Serbian and 143 respondents who reported that at most 10 per cent of the websites visited were in Serbian. Ukrainian is the official language of the Ukraine and is spoken by about 67 per cent of the population, ${ }^{33}$ while Russian is spoken by about 24 per cent of the population. The Russianspeaking industrialised eastern part of the Ukraine looks to Russia, while the Ukrainian-speaking agricultural western Ukraine is more nationalistic. ${ }^{35}$ In the Ukrainian sample this resulted in 103 respondents who reported that at least 30 per cent of the websites visited were in Ukrainian and 90 respondents who reported that at most 15 per cent of the websites visited were in Ukrainian. Many in the Ukrainian sample reported visiting websites in Russian; this was viewed as a relatively external orientation given the many nations of the former USSR that speak Russian. Thus, the relatively external versus local orientation focused on websites visited that were in Ukrainian. Similarly many in the Serbian sample reported visiting websites in English, suggesting that the Ukrainian sample's external view is to the East and the former USSR while the Serbian sample's external view is to the West.

Since preliminary analyses indicated that there were some country differences the independent variables consisted of: the six remaining psychographic variables; the demographic variables; the number of internet technologies used (maximum $=9$ ); the average number of hours spent weekly on the internet; the country where 
Table 4: Significant and marginally significant independent variables in the logistic regression equation

\begin{tabular}{|c|c|c|}
\hline Independent variable & $\begin{array}{l}\text { Regression } \\
\text { coefficient }\end{array}$ & Significance \\
\hline Sensory innovativeness & 0.153 & 0.001 \\
\hline $\begin{array}{l}\text { Sensory innovativeness } \\
\text { and Ukrainian }\end{array}$ & -0.142 & 0.015 \\
\hline Cognitive innovativeness & -0.090 & 0.072 \\
\hline $\begin{array}{l}\text { Cognitive innovativeness } \\
\text { and Ukrainian }\end{array}$ & 0.181 & 0.012 \\
\hline Gender & 0.689 & 0.061 \\
\hline Education & & 0.017 \\
\hline Secondary & 1.862 & 0.009 \\
\hline Some university & 1.192 & 0.028 \\
\hline Ukrainian and education & & 0.020 \\
\hline $\begin{array}{l}\text { Ukrainian and some } \\
\text { university }\end{array}$ & -2.119 & 0.007 \\
\hline $\begin{array}{l}\text { Ukrainian and average time } \\
\text { spent on internet }\end{array}$ & -0.057 & 0.078 \\
\hline $\begin{array}{l}\text { Ukrainian and attitude } \\
\text { towards computers }\end{array}$ & -0.181 & 0.090 \\
\hline
\end{tabular}

Model summary statistics:

Chi-square (Step, Block, and Model) $=78.604, \mathrm{df}=41$, $\mathrm{p}<0.001$

-2 Log likelihood=385.133

Cox and Snell R Square $=0.209$

Nagelkerke R Square $=0.279$

Correctly classified cases in the estimation sample $=71.9 \%$ (241/335)

Correctly classified cases in the holdout sample $=63.7 \%$ $(65 / 102)$

the sample was collected; and interactions of the country variable with all of the preceding variables. The interactions were computed by multiplying each variable by a dummy variable (0 if Serbian sample, 1 if Ukrainian sample). Thus, in Table 4 the interactions are those terms with Ukrainian in the label. This interaction approach allows testing for country differences in the slopes for each of the regression coefficients and for testing country differences in the intercept (ie Chow tests). A holdout sample of 189 respondents (23.7 per cent of the total sample) was generated using a uniform random number generator. Out of the 189 , only 102 had valid responses on the dependent variable and all independent variables. Thus, 335 cases (42 per cent of the total sample) were used to estimate the equation. All variables were entered into the equation and used to estimate the parameters.

The significant (in bold type) and marginally significant $(p<=0.10)$ independent variables are presented in Table 4. A positive regression coefficient on a main effect variable (ie not an interaction with country) indicates that higher values increase the likelihood that a person has a relatively external orientation, while a negative coefficient indicates that higher values lessen the likelihood of an external orientation. Similarly, negative coefficients on interactions with country (ie the Ukraine) indicate that higher values reduce the likelihood of an external orientation for the Ukrainian sample, while positive coefficients on interactions indicate that higher values increase the likelihood of an external orientation for the Ukrainian sample.

\section{Hypothesis testing results:}

Both the main and interaction effects of sensory innovativeness are significant but the coefficients are in different directions. Thus those in the Serbian sample who are high in sensory innovativeness are more likely to have an external orientation than those in the Ukrainian sample. The difference in the coefficients between the main effect and the interaction (ie sum is close to zero) indicates that sensory innovativeness has little discriminatory power for the Ukrainian sample. Thus, Hypothesis 1a is supported for the Serbian sample but not the Ukrainian sample.

The two effects related to cognitive innovativeness show a negative coefficient for the main effect but a much larger positive coefficient for the interaction. For the Serbian sample the interpretation is straightforward. The negative coefficient on the main effect indicates that higher levels of cognitive innovativeness are associated with a lower likelihood of an external orientation. For the Ukrainian sample, the addition of the significant interaction with country indicates that higher levels of cognitive innovativeness are more likely to be associated with an external orientation. Thus, Hypothesis $1 \mathrm{~b}$ is supported by the Serbian sample and rejected by the Ukrainian sample. Clearly innovativeness, both sensory and cognitive, is functioning differently in the two samples. Sensory innovativeness is positively related to an external orientation for the Serbian sample while unrelated for the Ukrainian sample. Cognitive 
innovativeness is positively related to external orientation for the Ukrainian sample and negatively related for the Serbian sample.

Opinion leadership was predicted to be negatively related to an external orientation. Neither the main effect nor the interaction was significant; therefore, Hypothesis 2 is not supported.

Consumer ethnocentrism was predicted to be negatively related to external orientation. Neither the main effect nor the interaction was significant so Hypothesis 3 is not supported.

Attitude towards computers, ownership of a PDA, ownership of a cellular telephone, ownership of a personal computer and number of internet technologies used were predicted to be positively related to an external orientation. None of these main effects were significant and only the interaction with attitude towards computers was significant so Hypotheses 4b, 4c, 4d and 4e were not supported. The negative coefficient on the significant interaction with attitude towards computers indicates that for the Ukrainian sample the more positive the attitude towards computers the less likely they are to have an external orientation. So not only is Hypothesis 4 a not supported, but also there is evidence for the opposite effect for the Ukrainian sample.

Web shopping risk attitude was expected to be negatively related to an external orientation. Neither the main effect nor the interaction was significant, so Hypothesis 5 was not supported.

It was expected that attitude towards advertising would be positively related to an external orientation. Unfortunately the scale reliability was too low and thus the construct was not used in the analyses. Thus, we are unable to test Hypothesis 6.

It was expected that males were more likely than females to have an external orientation. The marginally significant coefficient for gender indicates that females are more likely than males to have a global orientation. This is opposite from the prediction so Hypothesis 7a is not supported. Since the interaction is not significant we can conclude that gender has the same impact on orientation of web browsing in both samples.

It was expected that younger internet users would be more likely to engage in an external orientation. Since neither the main effect nor the interaction was significant, Hypothesis $7 \mathrm{~b}$ is not supported.

The significant positive main effect coefficient for those with a secondary education indicates that this group is more likely to have an external orientation. The lack of a significant interaction indicates that the impact of this education group is the same for both Serbs and Ukrainians. The combination of a positive main effect coefficient for those with some university education combined with a large significant negative coefficient on the interaction of country for those with some university education indicates that Ukrainians with some university education are not as likely as similarly educated Serbians to have an external orientation. Thus, for Serbians some university education makes them more likely to have an external orientation, but the opposite is true for the Ukrainians. Thus, there is some support for Hypothesis 7c from the Serbian sample, but the results suggest that secondary education is a better predictor of external orientation for both samples and for the Ukrainians some university is linked to an increased likelihood of a local orientation.

The marginally significant interaction of country with amount of time spent on the internet suggests that Ukrainians who spend more time on the internet are less likely than their Serbian counterparts to have an external orientation. This is the opposite of the prediction and therefore Hypothesis $7 \mathrm{~d}$ is not supported.

\section{Overall binary logistic model results:}

The classification results for both the analysis and holdout samples are presented in Table 5. Press's $Q$ statistic ${ }^{36}$ is used to assess the statistical significance of the classification results. It compares the number of cases correctly and incorrectly classified to the number of cases that you would expect to correctly and incorrectly classify and is distributed as a chi-square with one degree of freedom. The proportional chance criterion $^{37}$ was used to estimate the number of cases expected to be correctly and incorrectly classified. For the analysis sample the proportion expected to be correctly classified is 50.08 per 
Table 5: Classification results for analysis and holdout samples

\begin{tabular}{|c|c|c|}
\hline \multicolumn{3}{|l|}{ Analysis sample } \\
\hline Actual group & Local orientation & $\begin{array}{l}\text { External } \\
\text { orientation }\end{array}$ \\
\hline Local orientation & 114 & 46 \\
\hline External orientation & 48 & 127 \\
\hline \multicolumn{3}{|l|}{ Holdout sample } \\
\hline Actual group & Local orientation & $\begin{array}{l}\text { External } \\
\text { orientation }\end{array}$ \\
\hline Local orientation & 33 & 20 \\
\hline External orientation & 17 & 32 \\
\hline
\end{tabular}

cent or 168 cases. From Table 4, we can see that 241 cases were correctly classified and 94 incorrectly classified. The value of Press's $Q$ for the analysis sample is 63.63, which is highly significant $(p<0.001)$. In the holdout sample the proportion expected to be correctly classified is 50.07 per cent or 51 cases. In fact 65 cases were correctly classified and 37 incorrectly classified. The value of Press's $Q$ for the holdout sample is 7.686, which is significant $(p<0.01)$.

\section{DISCUSSION}

This study indicates that even within regions, there are sufficient differences from country to country that may make international marketers rethink their online communications strategies to date. While internet diffusion in emerging markets may be limited by infrastructure, this should not be the only consideration for international marketers. This study indicates that online populations in emerging markets may find global digital communications meaningful if they have an external orientation in web browsing. If on the other hand, the online population is more locally oriented, then international marketing communications via the internet may need to be tailored to the local needs and local ethnic portals may be more effective.

Psychological and demographic variables that are differentiators for US internet usage were also predictors for Serbia and the Ukraine. The significant effects of both sensory and cognitive innovativeness confirm the applicability of the construct and suggest that tapping both dimensions is fruitful. The high values on the sensory dimension increase the likelihood of an external orientation for Serbs while high values on the cognitive dimension increase the likelihood of an external orientation for Ukrainians. The impact of gender and education on web browsing behaviour also reflects the US experience. In the Ukrainian sample, some university education was linked to more locally oriented web browsing behaviour perhaps suggesting greater ethnocentrism. Ukrainians who are heavy internet users and Ukrainians with positive attitudes towards computers are also more likely to be locally oriented in web browsing. Segmenting on the basis of usage rate is a common tactic in US marketing so the usefulness of this variable also reflects the US experience. The most striking difference from US experiences is the lack of any effect of opinion leadership. Perhaps opinion leadership on internet usage in these countries only impacts use or nonuse of the internet. Perhaps these countries are still in such an early stage of adoption of the internet that it is primarily innovators who use the internet.

It is very clear that while the set of psychological and demographic variables used were useful predictors and, with one exception, had acceptable reliability, there were large differences in their impact between the two countries. The restriction of sampling to the major urban area in each country suggests caution in generalising beyond those two urban areas. Still those urban areas represent a very large proportion of the internet users in each country. Therefore, we cautiously suggest that our results have the following implications for managers depending on their desired target market and product/service:

1. If a product or service provides novel sensory experiences or can be promoted on that basis, a global or regional strategy would likely be effective in reaching Serbs.

2. If a product or service provides novel cognitive experiences or can be promoted on that basis, a global or regional strategy would likely be effective in reaching Ukrainians.

3. If the target market were those with a secondary education, a global or regional strategy would 
likely be effective in reaching both Serbs and Ukrainians.

4. If the target market consisted of those with some university education, then a locally oriented strategy would likely be effective in reaching Ukrainians, while a global or regional strategy would be effective in reaching Serbs.

\section{Acknowledgments}

We thank the participants at the Second Annual JIBS/AIB Paper Development Workshop and the South Carolina CIBER (sponsors of this event at the Academy of International Business Meeting in Quebec City in July 2005) for their invaluable critiques. Sincere thanks are also extended to Dr John S. Hill from the University of Alabama for his insight, editorial suggestions and timely feedback.

\section{References}

1 Financial Times. 20th November, 2006.

2 Lynch, P. D. and Beck, J. C. (2001) 'Profiles of internet buyers in 20 countries: Evidence for region-specific strategies', Journal of International Business Studies, Vol. 32, No. 4, pp. 725-748.

3 http://www.internetworldstats.com/stats.htm.

4 Laroche, M., Kirpalani, V. H., Pens, F. and Zhou, L. (2001) ‘ A model of advertising standardization in multinational corporations', Journal of International Business Studies, Vol. 32, No. 2, pp. 250-265.

5 DiGregorio, D., Kassicieh, S. and de Gouvea Neto, R. (2005) 'Drivers of e-business activity in developed and emerging markets', IBEE Transactions on Engineering Management, Vol. 52, No. 2, pp. 155-166.

6 Clarke, T. (2000) 'The use of foreign languages by Irish exporters', European Journal of Marketing, Vol. 34, No. 1/2, pp. 80-90.

7 Marcella, R. and Davies, S. (2004) 'The use of customer language in international marketing communication in the Scottish food and drink industry', European Journal of Marketing, Vol. 38, No. 11/12, pp. 1382-1385.

8 Agrawal, M. (1995) 'Review of a 40-year debate in international advertising', International Marketing Review, Vol. 12, No. 1, pp. 26-48.

9 Okazaki, S. (2004) 'Does culture matter? Identifying crossnational dimensions in Japanese multinationals' product-based websites', Electronic Markets, Vol. 14, No. 1, pp. 58-64.

10 Dou, W., Yoo, B. and Liangyu, B. M. (2003) 'Consumer patronage ethnic portals', International Marketing Review, Vol. 20, No. 6, pp. 661-678.

11 Robles, F. (2002) 'The evolution of global portal strategy', Thunderbird International Business Review, Vol. 44, No. 1, pp. 25-46.

12 Kotha, S., Rindova, V. and Rothaermel, F. (2001) 'Assets and actions: Firm-specific factors in the internationalization of U.S. Internet firms', Journal of International Business Studies, Vol. 32, No. 4, pp. 769-792.

13 Donthu, N. and Garcia, A. (1999) 'The Internet shopper', Journal of Advertising Research, Vol. 39, No. 3, pp. 52-58.
14 Blake, B., Neuendorf, K. and Valdiserri, C. (2003) 'Innovativeness and variety of Internet shopping', Internet Research, Vol. 13, No. 3, pp. 156-170.

15 Strauss, J., El-Ansary, A. and Frost, R. (2006) 'E-Marketing', 4th edn, Pearson Prentice-Hall, Upper Saddle River, NJ.

16 www.cia.gov/library/publications/the-world-factbook/index. html.

17 Meyer, K. E. (2001) 'International business research on transition economiesin Rugman, A. M. and Brewer, T. (eds), 'Oxford Handbook of International Business', Oxford University Press, Oxford, UK', pp. 716-759.

18 http://www.cdt.org/international/ceeaccess/countrydetail.shtml.

19 Donthu, N. and Gilliland, D. (1996) 'The infomercial shopper', Journal of Advertising Research, Vol. 36, No. 2, pp. 69-76.

20 Jarvenpaa, S. L. and Tractinsky, N. (1999) 'Consumer trust in an Internet store: A cross-cultural validation', Journal of Computer Mediated Communication, Vol. 5, No. 2. (Accessed online in 2002 at www.ascusc.org/jcmc/).

21 Cui, C. C. and Adams, E. I. (2002) 'National identity and NATID: An assessment in Yemen', International Marketing Review, Vol. 19, No. 6, pp. 637-662.

22 Venkatraman, M. P. and Price, L. L. (1990) 'Differentiating between cognitive and sensory innovativeness: Concepts, measurement, and implications', Journal of Business Research, Vol. 20, pp. 293-315.

23 Childers, T. L. (1986) 'Assessment of the psychometric properties of an opinion leadership scale', Journal of Marketing Research, Vol. 23, pp. 184-188.

24 King, C. W. and Summers, J. O. (1970) 'Overlap of opinion leadership across product categories', Journal of Marketing Research, Vol. 7, pp. 43-50

25 Evans, J. R. and Berman, B. (2005) 'Marketing in the 21st Century', 9th edn, Atomic Dog Publishing, Cincinnati, $\mathrm{OH}$.

26 Goldsmith, R. E. (2002) 'Explaining and predicting consumer intention to purchase over the Internet: An exploratory study', Journal of Marketing Theory and Practice, Vol. 2, No. 2, pp. 22-28.

27 Summers, J. O. (1971) 'Generalized change agents and innovativeness', Journal of Marketing Research, Vol. 8 (August), pp. 313-316.

28 Baumgarten, S. A. (1975) 'The innovative communicator in the diffusion process', Journal of Marketing Research, Vol. 12 (February), pp. $12-18$.

29 www.cc.gatech.edu/gvu/usersurveys/.

30 Onisimov, Y. (2002) 'Ukraine Internet rights country report', last updated on 8th May, 2002. Available online at www.apc.org/ english/rights/europe/countries/ukraine.html.

31 https://www.cia.gov/library/publications/the-world-factbook/ geos/up.html.

32 Markovic, S. (2002) 'Yugoslavia internet rights country report', last updated on 8th May, 2002. Available online at www.apc.org/ english/rights/countries/yugoslavia.html.

33 https://www.cia.gov/library/publications/the-world-factbook/ geos/rb.html.

34 Nunnally, J. C. (1978) 'Psychometric Theory', 2nd edn, McGraw-Hill, New York.

35 Quinn-Judge, P. and Zarakhovich, Y. (2004) 'The orange revolution', TIME: Europe Magazine. available online at www. time.com/europe/magazine/printout/0,13155,901041206832153,00.html.

36 Press, S. J. (1972) 'Applied Multivariate Analysis', Holt, Rinehart and Winston, New York.

37 Morrison, D. G. (1969) 'On the interpretation of discriminant analysis', Journal of Marketing Research, Vol. 6 (May), pp. 156-163. 